\title{
Basic Life Support: an accessible tool in layperson training
}

\author{
(1D) Carolina Reis Bonizzio ${ }^{1}$ \\ (iD) Christopher K. Nagao \\ (iD Gabriel B. Polho ${ }^{3}$ \\ (iD) Vitor R. Paes ${ }^{4}$
}

\begin{abstract}
1. Médica Generalista da FMUSP, diretora da Expedição Cirúrgica da Bandeira Científica (ECBC) em 2016, São Paulo, SP, Brasil
2. Médico Generalista da FMUSP, diretor da Expedição Cirúrgica da Bandeira Científica (ECBC)2016, São Paulo, SP, Brasil

3. Médico Generalista da FMUSP, membro da Expedição Cirúrgica da Bandeira Científica (ECBC) 2016, São Paulo, SP, Brasil 4. Médico patologista pela FMUSP, coordenador da Expedição Cirúrgica da Bandeira Científica (ECBC) em 2016 e orientador científico, São Paulo, SP, Brasil
\end{abstract}

http://dx.doi.org/10.1590/1806-9282.65.10.1300

\section{SUMMARY}

OBJECTIVES: 1) To evaluate the efficiency of a new method of training laypeople on cardiopulmonary resuscitation (CPR). 2) To assess previous knowledge of the participants.

METHODS: Instructors were trained according to the 2015 American Heart Association Guidelines, with emphasis on CPR. Dummies made with PET bottles were used, and a questionnaire was applied to the participants before and after training. Statistical analysis was performed in the R commander program. Participants with incomplete documents were excluded from the study.

RESULTS: Out of 101 participants, 96 were included: 69 lay people, 17 health professionals, and ten health students. There was an improvement in the overall performance after training (mean pre: $62.7 \%$, mean post: $75.8 \%, p<0.01$ ), also present in the following main concepts: "mouth-to-mouth breathing is not necessary" ( $p<0.01$ ), "risk of contamination" ( $p<0.01)$, "compression technique" ( $<0.01)$. The concepts "recognition of severity" and "what is chest compression" did not improve, but had good pre-test means, 96.8\% and 81.2\%. There was no statistical difference in the knowledge between the groups (laypeople vs. health professionals and students, pre=0,06 e post=0,33).

CONCLUSION: The tools used in training were efficient. However, further studies are necessary to assess the long-term impact of this intervention.

KEYWORDS: Cardiopulmonary Resuscitation. Out-of-Hospital Cardiac Arrest. Education. Manikins.

\section{INTRODUCTION}

Cardiovascular diseases have a high prevalence. According to the WHO, $19 \%$ of deaths worldwide in 2012 were due to cardiovascular diseases ${ }^{1}$. It is estimated that Brasil has 200 thousand cases of cardiac arrest (CA) annually, half of those in an extra-hospital environment, i.e., in homes and public places ${ }^{2}$. In these cases, the success rate is, on average, $10 \%^{3}$. In this context, it can be argued that laypeople will often witness a CA. Several studies point to the important role of cardiopulmonary resuscitation (CPR) executed by a spectator, which can increase the chances of survival of the victim by more than two times ${ }^{4}$. In view of this purpose, lay people can be trained without necessarily having to undergo extensive hours.

DATE OF SUBMISSION: 10-Mar-2019

DATE OF ACCEPTANCE: 31-Mar-2019

CORRESPONDING AUTHOR: Carolina Bonizzio

Av. Dr. Arnaldo, 455 - Sao Paulo - São Paulo - 01246-903 - Brasil

Tel.: (11) 985612725

E-mail: carolbonizzio@hotmail.com 
There are studies that show satisfactory learning of basic life support (BLS) using videos and/or dummies for training staff, even in short sessions ${ }^{5-8}$. In addition, the training is able to decrease anxiety in relatives of patients with high cardiovascular risk, which can be a barrier when assistance is actually required $^{9-11}$.

Therefore, it is known that the laypeople can provide initial CPR until the arrival of an Emergency Medical Service, such as the Samu (Emergency Medical Care Service), improving the outcome of many patients. For this to occur, it is necessary to educate and train the population.

\section{THE BANDEIRA CIENTÍFICA PROJECT AND THE SURGICAL EXPEDITION}

Considering the importance of the subject and the fact that the learning of BLS by laypeople is a subject that is poorly studied, the 4th Surgical Expedition of the The Bandeira Científica Project (ECBC) decided to carry out an educational program in a small Brazilian city.

The Bandeira Científica Project of the University of São Paulo is an academic extension program that exists since the 1950s and uses the principles of care, teaching, and research in their expeditions to remote regions of Brasil, promoting activities related to health, including medical care, with interventions with impact in the short and long term ${ }^{12}$. The ECBC, an academic extension program of the Medical faculty of the University of São Paulo (USP), started in 2013 and annually visits a Brazilian city to offer free elective surgeries in gynecology and gastric surgery. As part of their interventions with potential long-term impact, they carry out activities with the population. In 2016, the project visited the town of Bandeirantes (PR) and offered BLS training using low-cost mannequins, giving special attention to situations that can be potentially encountered by laypeople. Recently, the ECBC went through a process of renewal and is now known as the Surgical Expedition of FMUSP ${ }^{13}$.

\section{OBJECTIVES}

Evaluate the effectiveness of the new proposed CPR training to the lay population.

Evaluate the prior knowledge of the training participants.

\section{METHODS}

Work approved by the Research Ethics Committee of FMUSP (decision number: 1.604.841. CAAE: 57007616.4.0000.0065). Each participant signed an informed consent form to participate in the study and answered a questionnaire developed by the Nursing School of USP ${ }^{14}$ before and after the training. Next, we detail the process.

Pre-training: training of instructors and confection of dummies

The medical students of FMUSP selected to participate in the Surgical Expedition were trained by project directors (4th-year medical students) along with the medical advisor of the study and the coordinator of the Surgical Expedition 2016. The process consisted in the study of the reference material according to the guidelines of the American Heart Association $2015^{15}$ and in training the didactic approach to the simulation activity. In total, 16 students were trained to act as instructors in six stations on common emergencies (acute myocardial infarction with cardiac arrest - AMI with CPR; drowning; airway obstruction; seizures; amputation), including a local demand (injury by a yellow scorpion) ${ }^{16}$.

In relation to the support to AMI victim's with CPR, important concepts of the chain of survival were reviewed with the students: identifying an emergency, calling for help, correct technique of chest compression, emphasis in compressions/no need for ventilation. In the workshop, this knowledge was passed on and evaluated with attention to self-safety before starting the support measures, good positioning of the victim and the rescuer for the compressions, not bending the arms during compression, proper depth $(5$ to $6 \mathrm{~cm})$ and total return of the chest after each compression at a frequency of 100 to 120 per minute ${ }^{15}$.

To facilitate the training of a large number of people, it was necessary to create a didactic model from inexpensive and widely available material. Low-cost dummies were made based on the Mass Training Project, of the Society of Cardiology of the State of São Paulo (SOCESP), a campaign for training students of 8 th year of primary education ${ }^{17}$. We used a 2-littler bottle of polyethylene terephthalate (PET), a t-shirt, a material as filling (paper, newspaper, fabric, styrofoam), stapler, and a rope. Each pair of instructors made their own dummy: they stapled the hem, sleeves, and collar, and, through the collar, 
placed a PET bottle filled with water at the center of the $\mathrm{t}$-shirt. The remaining space was filled with their material of choice, and the collar was attached to the end of the bottle with the rope. In our activity, we opted to fill $70 \%$ of the bottle with water in order to increase the strength required for compression and thus give advice on the proper posture.

The Automatic External Defibrillator (AED) was not used to simplify the method, considering the profile of a small town, where there are not usually crowds that require the wide availability of the device $^{15}$.

\section{The training}

The event occurred in three periods of the same day, with the duration of $1 \mathrm{~h} 30 \mathrm{~min}$ each. The event was widely publicized during the permanence of the expedition in the city. The 16 students, divided into eight pairs, staged the six clinical scenarios, encouraging the participation of the population and guided the appropriate conduct.

\section{The questionnaire}

The main outcome of the study (learning with the method described) was assessed by a questionnaire drawn up at the Nursing School of USP and validated in 2009 only to evaluate the knowledge of laypeople on BLS. It contains multiple-choice and open-ended questions on the support using $\mathrm{CPR}^{14}$. The questionnaire used as reference guidelines outdated today, which did not yet include the non-necessity of mouth to mouth during CPR performed by a layperson. Given that we modified the original use of the questionnaire, some adjustments were necessary to interpret the answers found. Therefore, we separated the learning process in greater concepts.

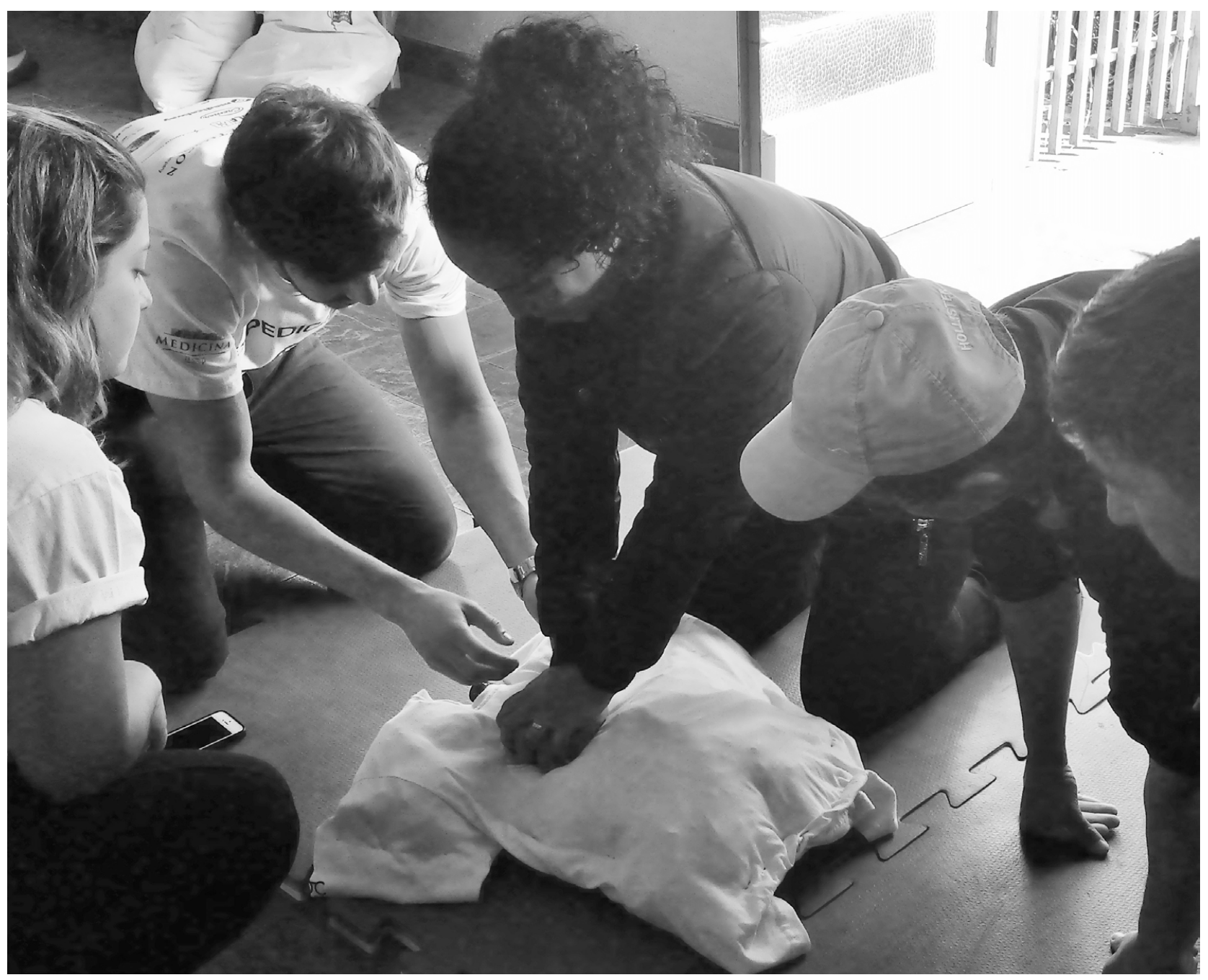

FIGURE 1. PARTICIPANTS RECEIVE INSTRUCTIONS ON THE USE OF THE DUMMY. 
The simplified questionnaire is as follows (full version in reference 14). Open-ended questions are highlighted ${ }^{*}$. The others were of multiple choice.

Q1. How can you check if the victim is breathing?

Q2. How is it possible to make it easier for the victim to breathe if there is no suspicion of fracture of the spine?

Q3. How is mouth-to-mouth breathing performed?

Q4*. Would you perform mouth to mouth breathing in an unknown person, without protective equipment? Why?

Q5*. Would you perform chest compressions even if you had not performed mouth to mouth breathing? Why?

Q6*. Do you know what are chest compressions, and what are they used for?

Q7. In what position must the victim be so that you can perform chest compressions?

Q8. What is the appropriate body site to perform chest compressions?

Q9*. Do you know the number of times chest compressions must be carried out, per minute, in an adult? If so, how many?

\section{Data Analysis}

Each question of the questionnaire received a grade that could be 2,1 , or 0 , depending on the participant's response. Therefore, the overall performance could vary from 0 to 18 points. For better data interpretation, the final score was calculated in the following way:. The questions on the questionnaire were divided into six clusters according to the objectives of the training: Identifying an emergency (Q1), Mouth to mouth breathing technique (Q2 and Q3), Identifying the risk of contamination in mouth to mouth breathing (Q4), Mouth to mouth breathing is not essential in cardiopulmonary resuscitation done by laypeople (Q5), The role of the chest compression (Q6), Chest compression technique (Q7, Q8 and Q9).

Three authors of the study participating in grading the questionnaires and standardized the score of the open-ended questions according to the learning objectives already mentioned, after a group discussion and consensus. In the multiple-choice questions, the score for each alternative marked ranged from 0 to 2 points. We followed the correction criteria used in the referenced study by the Nursing School of USP. According to that study, some alternatives were considered partially correct. Therefore, when chosen by the participants, they received half of the total score, i.e., 1 point.

Participants were divided into two groups in data analysis: participants in the health area (health students and professionals) and laypeople. The comparison between the performance pre- and post-intervention was performed by paired Student t-test. The significance level for all tests was $5 \%$. The tests were entered into Microsoft Excel (2010) or interface R commander of the R software, version 3.2.5 (2016).

\section{RESULTS}

Participants

In total, 101 people participated in the activity. Five were excluded due to incomplete documents (informed consent and questionnaire), leaving 96 valid questionnaires. Of these, 78 were women (81.2\%), and 18 were men (18.7\%). There were 69 laypeople (71.8\%), 17 health professionals (17.7\%), such as nurses and nursing technicians, and ten students in the area of health (10.4\%). The largest portion had at least secondary education (92\%), and the average age was 34 years (ranging between 14 and 55).

\section{Examples of open-ended answers}

Below, we explain the criteria for grading answers for each open-ended question using some examples (Table 1) found in the study.

Question 4: Would you perform mouth to mouth breathing in an unknown person, without protective equipment? Why?

The purpose of this question was to assess whether the participants had some notion of the biological risks to the rescuer, not being recommended to laypeople $^{14}$. Therefore, people who answered "no" and justified it by saying there is a "risk of transmission of diseases" and "the method is not necessary," had a maximum score (2 points). Those who would not perform the method but gave no valid justification received intermediate scores (1 point). People who answered "no" and did not present any justification and those who answered "yes," regardless of the justification, received no points. Of these, the most frequent justification was "to help/save."

Question 5: Would you perform chest compressions even if you had not performed mouth to mouth breathing? Why? 
TABLE 1. SCORE FROM OPEN-ENDED ANSWERS PREAND POST-TRAINING

\begin{tabular}{|c|c|c|}
\hline Questions & Answers & Score \\
\hline \multirow{7}{*}{$\begin{array}{l}\text { Answered negatively } \\
\text { to Q4 - Would you } \\
\text { perform mouth to } \\
\text { mouth breathing in } \\
\text { an unknown person, } \\
\text { without protective } \\
\text { equipment? Why? }\end{array}$} & Risk of disease transmission & 2 \\
\hline & It is not necessary & 2 \\
\hline & For personal safety & 2 \\
\hline & Unknown victim & 2 \\
\hline & Inexperience & 1 \\
\hline & I do not know how to do it & 1 \\
\hline & I do not know why & 0 \\
\hline \multirow{12}{*}{$\begin{array}{l}\text { Answered positively } \\
\text { to Q5: Would you } \\
\text { perform chest com- } \\
\text { pressions even if you } \\
\text { had not performed } \\
\text { mouth to mouth } \\
\text { breathing? Why? }\end{array}$} & Resume heartbeats & 2 \\
\hline & $\begin{array}{l}\text { Chest compressions are more } \\
\text { important }\end{array}$ & 2 \\
\hline & $\begin{array}{l}\text { Chest compressions are enough } \\
\text { to save }\end{array}$ & 2 \\
\hline & There is an important reserve of air & 2 \\
\hline & To stabilize the patient & 1 \\
\hline & To save & 1 \\
\hline & It is the right thing to do & 1 \\
\hline & It is necessary & 1 \\
\hline & $\begin{array}{l}\text { I believe in the saving power of the } \\
\text { compressions }\end{array}$ & 1 \\
\hline & To resume breathing & 0 \\
\hline & It is faster & 0 \\
\hline & It is easier & 0 \\
\hline \multirow{7}{*}{$\begin{array}{l}\text { Q6 - Do you know } \\
\text { what are to chest } \\
\text { compressions, and } \\
\text { what are they used } \\
\text { for? }\end{array}$} & Resuscitation/reanimation & 2 \\
\hline & Keep heartbeats & 2 \\
\hline & Get the heart to function again & 2 \\
\hline & $\begin{array}{l}\text { Assist in the circulation of blood to } \\
\text { the organs }\end{array}$ & 2 \\
\hline & Oxygenation of organs & 2 \\
\hline & To resume breathing & 0 \\
\hline & Force the air to exit & 0 \\
\hline \multirow{4}{*}{$\begin{array}{l}\text { Q9 - Do you know } \\
\text { the number of times } \\
\text { chest compressions } \\
\text { must be carried } \\
\text { out, per minute, in } \\
\text { an adult? If so, how } \\
\text { many? }\end{array}$} & 100 a 120 & 2 \\
\hline & $30 \times 2$ & 1 \\
\hline & $\begin{array}{l}\text { As long as necessary until help } \\
\text { arrives }\end{array}$ & 1 \\
\hline & Other values $(10,15,60)$ & 0 \\
\hline
\end{tabular}

In this question, we evaluated whether participants knew that chest compressions are crucial, to the detriment of mouth-to-mouth breathing. Those whose answer displayed these concepts received a maximum score. Inaccurate and generic justifications scored 1, and those that did not make sense or with wrong concepts received 0 points. Those who answered "no" to the first part of the question also did not receive any points, regardless of the justification. Of these, the most common justifications were: "Because it should be associated with mouth to mouth breathing," "I can cause injury to the victim," "I do not know how" and "I do not know why."
Question 6: Do you know what are chest compressions, and what are they used for?

Participants who explained the importance of chest compressions to maintain tissue oxygenation and/or restoration of blood circulation obtained a maximum score. This question did not offer intermediate scores. Participants who related to cardiac massage to the respiratory activity received 0 points.

Question 9: Do you know the number of times chest compressions must be carried out, per minute, in an adult? If so, how many?

Answers with a heart rate of 100 to 120 received 2 points. Other values received 0 points. Those who answered " $30 \times 2$ " received 1 point, because, despite the obvious error of interpretation of the question, we believe that the participants acquired a correct concept (30 compressions for two breaths in the care of the CPR in adults) presented during training.

\section{PRE- AND POST-TRAINING COMPARISON}

There was global learning, especially in relation to the concepts of "mouth to mouth breathing is not necessary," "risk of contamination" (in mouth to mouth breathing), "chest compression technique" and "breathing technique." The concepts of "identifying an emergency" and "role of chest compression" showed no statistically significant difference in learning, probably because the participants already had good knowledge of it prior to the activity. This can be observed by the high average of these concepts pre-training (see table 2).

\section{Differences between the groups}

No statistically significant difference was observed between the groups of laypeople (mean pre $60.46 \pm 14.17$; mean post $76.81 \pm 16.54$ ) and health professionals and students (mean pre $68.51 \pm 20.05$; mean post $73.25 \pm 16.9$ ) regarding their knowledge pre- $(\mathrm{p}=0.06)$ or post-training $(p=0.33)$. This contradicts the assumption that health professionals would already have prior knowledge superior to other participants. However, the groups did not have similar sizes (69 laypeople x 27 participants in the area of health), which may have interfered in the statistical power of the test. 


\section{DISCUSSION}

The high incidence of cardiovascular diseases, in addition to the possibility of emergency situations in extra-hospital environments, motivated this study. It is well known that as we move away from the large Brazilian metropolitan centers, the quality of education and health services offered to the population decreases progressively. Our proposal for first-aid training was designed to meet a large number of people without the need for rooms and technological material; with the minimum cost of a PET bottle, a well-prepared team is able to teach people in places with low technology available. In our study, the participants (related or not with the area of health) have increased their knowledge of CPR.

In comparison with the results of the study that developed the original questionnaire, the prior knowledge measured in 385 respondents in Campinas (SP) was lower than that found among the participants of the training in Bandeirantes (PR): mean of $40.8 \%$ of 7 points, and mean average of $62.7 \%$ of 18 points. Detailing the percentage of correct answers by the participants in Campinas for each question of the questionnaire, we have Q1 75.8\%; Q2 16.4\%; Q3 9.9\%; Q6 67\%; Q7 14.5\%; Q8 8.8\%; Q9 0\%. In all questions, the knowledge of untrained laypeople was lower than that found in the present study. The difference in formal education between participants of both studies may offer an explanation: while in the study by Pergola and Araujo14, 46.5\% completed secondary education and $34.8 \%$ higher education, in our study these figures were $62.3 \%$ and $27.5 \%$, respectively. In addition, there may be a selection bias, since the first study approached laypeople randomly on the street, while ours was announced by the media of the city.

Interestingly, we did not observe any difference in prior knowledge regarding BLS between laypeople and health professionals. This could indicate the lack of training on basic life support in health pro- gram in the region, as well as limitations in continuing education, essential for the subject. With regards to continuing education, Piepho et al. ${ }^{18}$ showed that lay people who participated in BLS training over ten years before were not able to reproduce the correct sequence of CPR. We also did not observe any difference in scores after the training, comparing the two groups, showing that the understanding of BLS approaches does not require specific knowledge. This result also shows us that the way the information was presented was appropriate to the general public.

The literature shows that laypeople with knowledge in BLS had better results in the practical evaluation using the dummy in comparison with laypeople with no prior knowledge. This remained the same even after the training, showing that taking classes again brings better results ${ }^{19}$. Our lay population was not tested in relation to previous BLS training, and our assessment was purely theoretical; however, as stated before, continuing education is necessary for proper learning. It is also worth noting that not only health professionals, but also health students, under professional supervision and after proper training, are able to instruct even without having completed the program, as shown in this study. It has also already been demonstrated that not only medical students but even trained laypeople could teach BLS in the same way that health professionals ${ }^{20,21}$. That is a good thing, because it offers more options for planning an educative action for the population.

We also noted that the main gain offered by the activity was in relation to the technique of compression and mouth to mouth breathing. Participants already had sufficient previous knowledge about the other matters (except risks of mouth to mouth breathing). Therefore, training with low-cost models was an efficient strategy to teach the technique of BLS procedures. Although the results may not be fully extrapolated to the general population, data suggest that BLS training programs should focus

TABLE 2. PERCENTAGE OF CORRECT ANSWERS ACCORDING TO THE CLUSTERS (MAJOR CONCEPTS)

\begin{tabular}{l|l|l|l|l|l|l} 
& $\begin{array}{l}\text { Identifying an } \\
\text { emergency (Q1) }\end{array}$ & $\begin{array}{l}\text { Mouth to mouth } \\
\text { breathing tech- } \\
\text { nique (Q2, Q3) }\end{array}$ & $\begin{array}{l}\text { Risk of contami- } \\
\text { nation (Q4) }\end{array}$ & $\begin{array}{l}\text { Mouth } \\
\text { to mouth } \\
\text { breathing is not } \\
\text { required (Q5) }\end{array}$ & $\begin{array}{l}\text { Role of chest } \\
\text { compression } \\
(\mathrm{Q} 6)\end{array}$ & $\begin{array}{l}\text { Chest com- } \\
\text { pression } \\
\text { technique } \\
(\mathrm{Q} 7, \mathrm{Q8}, \mathrm{Q} 9)\end{array}$ \\
\hline $\begin{array}{l}\text { Average Pre- } \\
\text { Train. }\end{array}$ & $\begin{array}{l}96.8 \% \\
( \pm 17.5)\end{array}$ & $\begin{array}{l}66.7 \% \\
( \pm 30.5)\end{array}$ & $57.3 \%( \pm 48.1)$ & $\begin{array}{l}30.7 \% \\
( \pm 38.6)\end{array}$ & $\begin{array}{l}\text { Total } \\
( \pm 39.2)\end{array}$ & $\begin{array}{l}55.0 \% \\
( \pm 19.4)\end{array}$ \\
\hline $\begin{array}{l}\text { Average } \\
\text { Post-Train. }\end{array}$ & $\begin{array}{l}98.9 \% \\
( \pm 10.2)\end{array}$ & $\begin{array}{l}73.9 \% \\
( \pm 26.4)\end{array}$ & $73.4 \%( \pm 43.5)$ & $\begin{array}{l}54.7 \% \\
( \pm 45.3)\end{array}$ & $\begin{array}{l}82.3 \% \\
( \pm 38.4)\end{array}$ & $\begin{array}{l}75 \% \\
( \pm 21.1)\end{array}$ \\
\hline T-Test & $\mathrm{P}=0.16$ & $\mathrm{P}<0.05$ & $\mathrm{P}<0.01$ & $\mathrm{P}<0.01$ & $\mathrm{P}=0.41$ & $\mathrm{P}<0.01$ \\
\hline
\end{tabular}


the technique on chest compression alone to bring new knowledge to the target audience, whose longterm retention was shown by Nishiyama et al..$^{22}$ to be superior to conventional training. A Danish study that distributed ResusciAnne dummies for training laypeople associated with the DVD lessons evaluated some concepts similar to those that we evaluated. In that study, the results were based only on the performance of CPR by participants before and after 3.5 months: there was an increase from $15 \%$ to $28 \%$ in the correct performance of the maneuvers of the opening the airways (similar to Q2 and Q3), a decrease from $24 \%$ to $13 \%$ in the correct position of the hands (similar to Q8), an increase from $4 \%$ to $23 \%$ in the correct frequency of compressions, and an increase from $55.2 \%$ to $70.8 \%$ in overall performance $^{5}$. An overall higher score on the questionnaire that we use can be attributed to the presence of multiple-choice questions, which can induce the correct answer and allow adjustments without true knowledge. In contrast, the practical assessment of CPR would be more reliable as to the skills of the participant.

The results presented here should be interpreted in light of some limitations. Firstly, the questionnaire was validated for a cross-sectional evaluation of the knowledge of laypeople on BLS and not as a tool to assess learning in the long term. This can be observed in the fact that there were many open-ended questions that allowed freedom of answer; which make it more difficult to group answers and perform a quantitative comparison. In relation to the questionnaire, it also did not assess recognition of CPR, nor how to follow in the CPR Chain of Survival outside a hospital environment, as recommended by the AHA, as well as the learning in other conditions simulated in the same training, which can serve as a basis for future studies. Secondly, we found that the average educational level of participants was high and most were females, which does not represent the population profile of Bandeirantes ${ }^{23}$, thus limiting the extrapolated interpretation of the data, which can involve a selection bias already discussed. Thirdly, the dummies did not provide feedback on the quality of chest compression. Some points of chest compression, therefore, may not have been adequately trained (such as the depth of compression) and make it impossible for a proper comparison with other studies in the same area. However, we found that low-cost materials can be used to demonstrate mainly the frequency of compressions, posture, and position of the hands-on practical activities, making them an interesting alternative in places with few resources.

\section{CONCLUSION}

We have demonstrated that the teaching of Cardiopulmonary Resuscitation using a low-cost model allows the retention of basic knowledge on basic support to life, at least in the short term, for a population with medium to high formal education. However, it is necessary to develop a tool more suitable for assessing the theoretical-practical learning of people and verify the effects of this method of teaching in the long term.

Since the Surgical Expedition of FMUSP annually visits a different Brazilian city, there are new opportunities for improving and adjusting our method in future studies.

\section{RESUMO:}

OBJETIVOS: 1) Avaliar a eficiência da nova proposta de ensino de ressuscitação cardiopulmonar (RCP) à população leiga. 2) Avaliar o conhecimento prévio dos participantes da oficina.

MÉTODOS: Instrutores foram treinados de acordo com as diretrizes de 2015 da American Heart Association com enfoque na RCP. Utilizaram-se manequins confeccionados com garrafas PET, além de aplicação de questionário aos participantes antes e depois do treinamento. A análise estatística foi realizada no programa $R$ commander. Foram excluídos do estudo participantes com documentos incompletos.

RESULTADOS: Dos 101 participantes, 96 foram incluídos: 69 leigos, 17 profissionais da saúde e dez estudantes da área da saúde. Houve melhora do desempenho geral após o treinamento (média pré: 62,7\%; média pós: 75,8\%; p<0,01), presente também nos seguintes conceitos principais: "respiração boca a boca não é necessária" ( $p<0,01)$, "risco de contaminação" ( $p<0,01)$, "técnica de compressão" ( $p<0,01)$. Os conceitos "reconhecimento de gravidade" e "o que é massagem cardíaca" não apresentaram melhora, mas tiveram boas médias pré-teste: $96,8 \%$ e 81,2\%. Não se verificou diferença estatística no conhecimento entre grupos (leigos vs profissionais e estudantes da saúde, ppre=0,06 e ppos=0,33). 
CONCLUSÃO: As ferramentas utilizadas no treinamento se mostraram eficientes. No entanto, novos estudos são necessários para avaliar o impacto no longo prazo.

PALAVRAS-CHAVE: Reanimação cardiopulmonar. Parada cardíaca extra-hospitalar. Educação. Manequins.

\section{REFERENCES}

1. World Health Organization. Global status report on noncommunicable diseases 2014. Geneva: World Health Organization; 2014.

2. Gonzalez MM, Timerman S, Gianotto-Oliveira R, Polastri TF, Canesin MF, Schimidt A, et al. I Diretriz de ressuscitação cardiopulmonar e cuidados cardiovasculares de emergência da Sociedade Brasileira de Cardiologia. Arq Bras Cardiol. 2013;101(2-suppl. 3):1-221.

3. Benjamin El, Blaha MJ, Chiuve SE, Cushman M, Das SR, Deo R, et al. Heart disease and stroke statistics-2017 update: a report from the American Heart Association. Circulation. 2017;135(10):e146-e603.

4. Blewer AL, Ibrahim SA, Leary M, Dutwin D, McNally B, Anderson ML, et al. Cardiopulmonary resuscitation training disparities in the United States. J Am Heart Assoc. 2017;6(5). Pii: e006124.

5. Nielsen AM, Henriksen MJ, Isbye DL, Lippert FK, Rasmussen LS. Acquisition and retention of basic life support skills in an untrained population using a personal resuscitation manikin and video self-instruction (VSI). Resuscitation. 2010;81(9):1156-60.

6. Isbye DL, Rasmussen LS, Lippert FK, Rudolph SF, Ringsted CV. Laypersons may learn basic life support in 24 min using a personal resuscitation manikin. Resuscitation. 2006;69(3):435-42

7. Lynch B, Einspruch EL, Nichol G, Becker LB, Aufderheide TP, Idris A. Effectiveness of a 30-min CPR self-instruction program for lay responders: a controlled randomized study. Resuscitation. 2005;67(1):31-43.

8. Potts J, Lynch B. The American Heart Association CPR Anytime Program: the potential impact of highly accessible training in cardiopulmonary resuscitation. | Cardiopulm Rehabil. 2006;26(6):346-54.

9. Flint LS Jr, Billi JE, Kelly K, Mandel L, Newell L, Stapleton ER. Education in adult basic life support training programs. Ann Emerg Med. 1993;22(2 Pt 2):468-74.

10. Sigsbee MS, Geden EA. Effects of anxiety on family members of patients with cardiac disease learning cardiopulmonary resuscitation. Heart Lung. 1990;19(6):662-5.

11. Cartledge S, Bray JE, Leary M, Stub D, Finn J. A systematic review of basic life support training targeted to family members of high-risk cardiac patients. Resuscitation. 2016;105:70-8.

12. Bandeira Científica [Internet]. Quem somos [cited on 30 Jun 2018]. Available from: www.bandeiracientifica.com.br/institucional/detalhar/1/historico

13. Expedição Cirúrgica da Faculdade de Medicina da Universidade de São Paulo [Internet]. Expedição cirúrgica [cited on 30 Jun 2018]. Available from: www2.fm.usp.br/expedicaocirurgica/index.php

14. Pergola AM, Araujo IEM. O leigo e o suporte básico de vida. Rev Esc Enferm USP. 2009;43(2):335-42.

15. Kleinman ME, Brennan EE, Goldberger ZD, Swor RA, Terry M, Bobrow B], et al. Part 5: Adult Basic Life Support and Cardiopulmonary Resuscitation Quality: 2015 American Heart Association Guidelines Update for Cardiopulmonary Resuscitation and Emergency Cardiovascular Care. Circulation. 2015;132(18 Suppl 2):S414-35.

16. Rocha M. Suporte básico de vida e socorros de emergência [Internet]. Brasília: AVM Instituto; 2011. [cited on 20 Nov 2017]. Available from: www. portaldaemergencia.com.br/estudos

17. SOCESP 2015 [Internet]. Treinamento em massa - SOCESP [cited on 20 Nov 2017]. Available from: www.socesp2015.com.br/treinamentoemmassa

18. Piepho T, Resch N, Heid F, Werner C, Noppens RR. Lay basic life support: the current situation in a medium-sized German town. Emerg Med J. 2011;28(9):786-9.

19. Wiese $\mathrm{CH}$, Wilke $\mathrm{H}$, Bahr I, Graf BM. Practical examination of bystanders performing Basic Life Support in Germany: a prospective manikin study. BMC Emerg Med. 2008;8-14.

20. Srivilaithon W, Amnaumpatanapon K, Limjindaporn C, Imsuwan I, Daorattanachai K. Study of basic-life-support training for college students. | Med Assoc Thai. 2015;98(Suppl 2):S145-50.

21. Beck S, Issleib M, Daubmann A, Zöllner C. Peer education for BLS-training in schools? Results of a randomized-controlled, noninferiority trial. Resuscitation. 2015;94:85-90

22. Nishiyama C, Iwami T, Kitamura T, Ando M, Sakamoto T, Marukawa S, et al. Long-term retention of cardiopulmonary resuscitation skills after shortened chest compression-only training and conventional training: a randomized controlled trial. Acad Emerg Med. 2014;21(1):47-54.

23. Instituto Brasileiro de Geografia e Estatística (IBGE) [Internet]. Cidades. Bandeirantes - PR [cited on 30 Jun 2018]. Available from: https://cidades. ibge.gov.br/brasil/pr/bandeirantes/panorama 